\title{
Monoclonal Hematopoietic Stem and Progenitor Cells Present
}

National Cancer Institute

\section{Source}

National Cancer Institute. Monoclonal Hematopoietic Stem and Progenitor Cells Present. NCI Thesaurus. Code C162191.

A finding indicating the presence of a monoclonal population of hematopoietic stem and progenitor cells in a tissue sample. 